\title{
DECISION USEFULNESS: DALAM PENGAMBILAN KEPUTUSAN DAN INVESTASI
}

\author{
Ahmad Fahrudin A \\ Fakultas Ekonomi,Universitas Islam Negeri Maulana Malik Ibrahim Malang \\ JI. Gajayana 50 Malang Telp. 0341-551354 Faks. 0341-572533 \\ HP : 08123393789. e-mail : afahrudin.feuin@gmail.com/
}

\begin{abstract}
This paper discusses the financial report based on historical prices. Using historical price makes it useful even today emerged another method. To quickly understand this concept, we need to consider other theories of the economics and finance. As an accountant, you can not begin to make financial statements more useful to us to know what is meant by usefulness. We also need a proper description of the information. Decision theory and the theory of investment helps in understanding the concepts of financial reporting information.
\end{abstract}

Keyword: Decision Usefulness, Investment, Judgment

\section{PENDAHULUAN}

Pemberlakuan akuntansi berdasarkan historical cost pada kelompok-kelompok besar terhadap aktiva-aktiva dan hutang telah disepakati untuk digunakan di dalam praktik, pertanyaan berikutnya adalah bagaimana laporan keuangan yang didasarkan pada historical cost dapat dibuat lebih bermanfaat? Hal ini mengarah pada suatu konsep penting dalam akuntansi yaitu konsep decision usefulness. Untuk memahami secara tepat konsep ini, kita perlu mempertimbangkan teori lain dari sisi ekonomi dan keuangan. Sebagai akuntan kita tidak dapat memahami laporan keuangan yang lebih bermanfaat sampai kita mengetahui apa yang dimaksud dengan bermanfaat dan mengetahui defenisi dari informasi yang tepat. Teori keputusan dan teori pasar modal membantu dalam memahami konsep dari informasi laporan keuangan.

Ada dua cara untuk menilai dampak-dampak keputusan pelaporan keuangan (Deegan, 2004) yaitu :

a. Menentukan dampak informasi kepada keputusan-keputusan para pemakai individu (perilaku)

b. Menentukan dampak apa yang dimiliki pengeluaran informasi pada harga saham (pasar modal). 
Ada empat alasan respon pasar berfokus terhadap pengumuman pendapatan akuntansi (Brown, $\mathrm{h}$. 24) dalam Deegan (2004) sesuai dengan dewan standar akuntansi keuangan, yaitu :

- informasi tentang pendapatan dan komponen-komponennya adalah tujuan utama pelaporan keuangan,

- pendapatan berorientasi terhadap kepentingan para pemegang saham yang merupakan suatu kelompok penting pemakai laporan keuangan,

- pendapatan adalah bilangan yang paling banyak dianalisis dan diramalkan oleh para analis sekuritas, dan

- data yang dipercaya tentang pendapatan tersedia dengan mudah.

Akuntan telah mengadopsi pendekatan keputusan dan manfaat terhadap laporan keuangan sebagai suatu reaksi terhadap kemustahilan untuk menyediakan laporan keuangan yang benar menurut teori. Bagaimanapun pendekatan ini memecahkan masalah terhadap pengidentifikasian para pemakai laporan keuangan dan pemilihan informasi yang mereka butuhkan untuk membuat keputusan yang baik. Sebagaimana yang diasumsikan bahwa investor bersikap rasional yakni selalu menghindari risiko (risk averse).

Dengan asumsi itu, maka para investor merupakan pihak yang berkepentingan untuk memperoleh informasi yang reliable dan relevan serta didukung dengan analisis-analisis didasarkan pada berbagai macam teori, khsususnya teori tentang decision dan investment. Berikutnya dijelaskan beberapa teori tentang hal itu.

\section{Single Person Decision Theory}

Single person decision theory memandang individu yang harus membuat keputusan dalam kondisi ketidakpastian. Teori ini mengenali bahwa kemungkinan keadaan tidak lagi obyektif sepeti pada kondisi ideal, dan di luar prosedur formal dalam individu dapat membuat keputusan terbaik dengan menseleksi dari sekelompok alternatif. Prosedur ini membolehkan informasi tambahan untuk diikuti guna merevisi penilaian subyektif pembuat keputusan yang mungkin terjadi setelah keputusan dibuat. Decision Theory relevan untuk akuntansi karena laporan keuangan menyediakan informasi tambahan yang berguna untuk banyak keputuasan.

Informasi laporan keuangan berguna bagi investor untuk memprediksi pengembalian investasi dimasa yang akan datang. Kemudian prediksi ini gunakan digunakan investor untuk memprediksi return investasi yang akan mereka pilih. Jalur alternatif tentang proses pengambilan 
keputusan investasi adalah bahwa investor menggunakan laporan keuangan terbaru untuk memprediksi cash flow, bukannya memprediksi earning power. Kemudian prediksi cash flow ini digunakan untuk memprediksi return. Sebelumnya kita mengetahui bahwa cash flow-lah yang menentukan nilai perusahaan pada masa yang akan datang. Bagaimanapun dibawah kondisi yang tidak ideal, adalah lebih baik jika menggunakan earning power untuk memprediksi return dari pada menggunakan cash flow. Dalam jangka panjang, kedua pendekatan ini kelihatannya sama karena pada akhirnya cash flow dan earning power mempunyai rata-rata yang sama.

Informasi menurut decision theory didefinisikan sebagai bukti yang potensial untuk mempengaruhi keputusan individual. Decision Theory diperlukan untuk memahami mengapa informasi itu komoditas yang kuat, yang bisa berdampak pada langkah yang diambil oleh investor. Akuntan yang menyediakan banyak informasi yang dibutuhkan oleh investor perlu untuk mengetahui peranan yang kuat. Karakteristik informasi akuntansi dapat dimengerti dengan memakai konsep sistem informasi, yang memberikan kemungkinan bahwa laporan keuangan akan memberikan berita baik dan buruk dari kondisi tiap keadaan.

\section{Theory of Investment}

Teori investasi adalah suatu spesialisasi atau bersifat opsional dari decission theory untuk menggambarkan proses pengambilan keputusan investor yang rasional. Dalam teori keputusan, konsep individu rasional yang sederhana berarti bahwa dalam pembuatan keputusan, keputusan yang dipilih adalah yang memiliki hasil utilitas yang diharapkan tertinggi. Hal ini memuat individu mencari informasi tambahan yang relevan dengan keputusan, dengan menggunakan Dalil Bayes untuk memperbaiki/meninjau kembali probabilitas.

Secara khusus, teori investasi membantu kita untuk memahami sifat dasar dari risiko dalam konteks investasi portofolio. Salah satu jalan investor dapat menurunkan resiko untuk expected return yang diberikan adalah dengan mengadopsi strategi diversifikasi, yaitu investasi dalam sekuritas portofolio. Prinsip diversifikasi portofolio menunjukkan kepada kita bahwa beberapa, tetapi tidak semua, resiko dapat dihilangkan dengan strategi investasi yang sesuai. Prinsip ini memiliki implikasi yang penting bagi sifat informasi risiko yang diinginkan investor.

Pendekatan keputusan yang bermanfaat pada laporan keuangan termasuk kebutuhan akuntan untuk memahami masalah keputusan dari pengguna laporan keuangan. Teori keputusan tunggal dan spesialisasinya pada keputusan investasi portofolio melengkapi pengertian dari 
kebutuhan rasional, menghindari resiko investor. Teori ini memberitahukan kita bahwa banyak investor membutuhkan informasi untuk menolong mereka menilai perolehan sekuritas harapan dan bahaya dari perolehan ini. Pada teori investasi, beta merupakan ukuran resiko penting, yang menjadi standar kovarians dari perolehan sekuritas dengan perolehan pada pasar portofolio. Resiko kovarians ini adalah komponen utama yang beresiko dari penggantian portofolio, bahkan jika portofolio berisikan hanya relatif beberapa sekuritas saja.

FASB dan SFAC menggambarkan perpaduan penting dari teori keputusan akuntansi keuangan dan pelaporan. Selanjutnya, teori ini ditetapkan dalam SFAC 1 untuk sebuah teori dari pembuatan keputusan untuk investor, yang mana telah banyak dipelajari dalam ekonomi dan keuangan. SFAC 2 menjalankan sebuah pendekatan keputusan yang bermanfaat pada peningkatan karakter bahwa informasi akuntansi akan mempunyai kegunaan. Pada intinya, informasi akuntansi mempunyai dua karakter besar informative adalah relevan dan kejujuran.

\section{Pendekatan Decision Usefulness}

Pendekatan decision usefulness untuk teori akuntansi mengambil tinjauan bahwa "jika kita tidak dapat menyajikan laporan keuangan secara teoritis benar, sedikitnya kita mecoba untuk membuat laporan yang berdasarkan pada harga historis yang lebih bermanfaat". Ada dua hal penting dalam mengadopsi pendakatan decision usefulness:

1. Siapa pengguna laporan keuangan?

Para Pengguna tersebut dapat dikategorikan dalam kelompok besar seperti investor, kreditur, manajer, serikat pekerja, pemakai standar, dan pemerintah. Kelompok ini disebut "constituencies" of accounting.

2. Keputusan apa yang dihadapi oleh pengguna?

Akuntan akan menyediakan laporan keuangan yang lebih baik untuk memenuhi informasi yang dibutuhkan pada "constituencies". Laporan keuangan kemudian dapat disajikan dengan informasi sesuai dengan yang dibutuhkan oleh para pengguna yang akan memberi petunjuk untuk memperbaiki pembuatan keputusan. Dengan kata lain, laporan keuangan dibuat lebih bermanfaat.

Pendekatan decision usefulness terhadap laporan keuangan ini sebagai suatu reaksi terhadap kemustahilan untuk menyedikan laporan keuangan yang benar menurut teori. Bagaimanapun pendekatan ini memecahkan masalah terhadap pengidentifikasian para pemakai 
laporan keuangan dan pemilihan informasi yang mereka butuhkan untuk membuat keputusan yang baik. Akuntan telah memutuskan bahwa para investor merupakan kelompok pengguna yang besar dan telah dikombinasikan dengan beberapa teori ekonomi dan keuangan, secara khusus keputusan investasi, untuk memahami bentuk-bentuk informasi laporan keuangan yang dibutuhkan oleh investor.

\section{Teori Pengambilan Keputusan Seseorang}

a. Garis Besar Metodologi

Teori pengambilan keputusan orang pribadi mengambil sudut pandang dari seseorang yang secara individu harus membuat keputusan dalam kondisi tidak pasti. Teori ini menyatakan bahwa pernyataan kemungkinan bukan tujuan jangka yang lebih panjang, seperti mereka dalam kondisi yang ideal, dan serangkaian prosedur formal dimana secara individu dapat membuat keputusan terbaik dengan memilih dari berbagai alternative. Prosedur ini memberikan informasi tambahan untuk memperbaiki perkiraan subyektif para pembuat keputusan. Dari kemungkinan apa yang mungkin terjadi setelah keputusan dibuat.

\section{b. Sistem Informasi}

Menurut Kieso (1995:53), informasi akuntansi dapat dikatakan andal jika memenuhi tiga karakteristik utama, yaitu dapat periksa, jujur dalam penyajian, dan netral. Sebaliknya, informasi akuntansi dapat dikatakan relevan jika mempunyai nilai prediktif dan nilai umpan balik. Informasi adalah bukti yang memiliki potesi untuk mempengaruhi keputusan individu (scoot, 2003). Informasi relevan adalah informasi yang memiliki kualitas revelan kalau dapat mempengaruhi keputusan ekonomi pemakai dengan membantu mereka mengevaluasi peristiwa masa lalu, masa kini, atau masa depan, menegaskan atau mengoreksi hasil evaluasi mereka pada masa lalu (IAI, 2009). Baridwan (1999:5) mengatakan bahwa relevansi dapat dihubungkan dengan tujuan penggunaannya, yaitu untuk pengambilan keputusan. Konsep nilai informasi dari system informasi bermanfaat dalam memahami peranan informasi dalam pengambilan keputusan. Semakin tinggi probabilitas 'main diagonal' terhadap 'off-main diagonal', semakin informatif sistem tersebut, atau dengan kata lain, semakin sedikit kandungan 'noise' didalmnya. Maka dari itu, semakin informative system informasi, semakin bermanfaat bagi keputsuan. Hal ini memungkinkan prediksi yang lebih baik mengenai laporan relevan dari sifat dan hasil (payoff). Dalam konteks investasi, payoff ini adalah Return on Investment (ROI). Sistem Informasi bisa bermanfaat bila laporan keuangan dapat 
memprediksi penghasilan dari investasi di masa depan, disamping itu laporan keuangan masih ada manfaatnya bagi investor untuk memprediksi good news atau bad news untuk waktu yang akan datang.

\section{Rasional, Investor Risk- Averse}

Konsep individu yang rasional secara sederhana berarti bahwa dalam membuat keputusan, tindakan yang dipilih adalah yang dapat menghasilkan kemanfaatan yang diharapkan paling besar akan tetapi individu yang "risk averse" akan melakukan "trade off " pengambilan yang diharap dengan resiko. Konsep ini berarti bahwa investor memerlukan informasi mempertimbangkan resiko dan juga expected value return masa depan.

\section{Prinsip Diversifikasi Portofolio}

Dalam konsep ini investor mengadopsi trade off antara resiko dan return; semakin tinggi resiko akan ditanggung hanya jika expected return lebih tinggi dan lain-lain. Salah satu jalan investor dapat menurunkan resiko untuk expected return yang diberikan adalah dengan mengadopsi strategi diversifikasi, yaitu investasi dalam sekuritas portofolio.

Investor menghindari resiko dengan mengambil dari prinsip diversifikasi Portofolio untuk mengurangi resiko mereka menanamkan modal dalam suatu portofolio surat berharga. Hal ini dikarenakan adanya keadaan spesifikasi perusahaan investor memerlukan kejelasan tertentu jika kita mengasumsikan mean-variance utility. Kemudian, dengan mengabaikan derajat tingkat resiko, kita mengetahui bahwa utility meningkatkan pengembalian yang diharapkan dan penurunan variance dari portofolio

\section{Keputusan Investasi yang Optimal}

Keputusan investsi bisa dikatakan optimal apabila jumlah investasi yang sama dalam portofolio dapat menghasilkn resiko yang lebih rendah dibanding jika diinvestasikan pada satu perusahaan untuk tingkat pengembalian yang diharapkan sama

\section{Resiko Portofolio}

Perhitungan dan Penaksiran Beta. Beta pengukuran yang berarti diantara perubahan harga saham dan perubahan didalam nilai pasar terhdap pasar saham. 


\section{Reaksi dari profesi akuntan untuk suatu pendekatan decision usefulness}

Tujuan utama dari laporan keuangan yaitu menyediakan informasi yang berguna untuk seorang investor kontensial dan kreditor, pengguan yang lain dalam pembuatan investasi rasional, kreditor, dan beberapa keputusan. Pembuat keputusan merupakan orang yang menghasilkan penyesuaian dalam teori, maksudnya orang yang membuat keputusan untuk memaksimumkan tujuan penggunaan yang diharapkan mereka yang biasa disebut rasional. Jenis dari konstitusi termasuk dalam sebagian besar tujuan umum (investor yang sekarang dan investor potensial dan kreditur dan pengguna yang lain ) dan juga jenis luas dari keputusan yang dikontemlasikan (Investasi, kredit, dan beberapa keputusan ).

Sedangkan menurut SFAC 1 Tujuan kedua laporan keuangan adalah menyediakan informasi untuk membantu investor sekarang, investor potensial, kreditor dan pengguna yang lain dalam menafsir jumlah waktu dan ketidaktepatan dari penerimaan kas dari dividen atau bunga. Pada intinya, informasi ketepatan akan melengkapi system informasi yang informartive yang berhubungan langsung laporan keuangan dengan kesadaran keadaan masa mendatang dan hasil. Dua karakter besar informative adalah relevan dan kejujuran. Informasi yang relevan adalah informasi yang mempunyai kapasitas pengaruh kepercayaan investor tentang perolehan dimasa mendatang. Kejujuran informasi juga pengaruh kepercayaan dari gambaran kesetiaan yang berarti ukuran. itu sakan menjadi teliti dan bebas dari penyimpangan.

\section{Perspektif Informasi pada Kebermanfaatan Keputusan}

Jika teori pasar yang efisien dan teori keputusan yang mendasarinya merupakan penjelasan yang logis mengenai realitas, kita perlu meneliti nilai pasar saham yang memberikan respon terhadap informasi baru dengan cara yang bisa diperkirakan. Riset akuntansi menegaskan bahwa harga pasar saham dalam kenyataannya memberikan respon paling tidak pada komponen penghasilan bersih dari informasi akuntansi. Bukti pertama disampaikan oleh Ball dan Brown pada tahun 1968. Semenjak itu, banyak penelitian empiris yang mencatat aspek tambahan dari respon pasar saham.

Berdasarkan penelitian ini, nampak bahwa informasi akuntansi berguna bagi investor dalam membantu memperkirakan nilai dan resiko hasil saham yang diharapkan. Pada intinya, informasi dianggap berguna jika mendorong investor untuk mengubah keyakinan dan tindakan 
mereka. Lebih lanjut, tingkat kegunaan bisa diukur dengan perkembangan perubahan harga setelah dikeluarkannya informasi. Perbandingan kegunaan dengan isi informasi disebut perspektif informasi pada laporan keuangan, suatu pendekatan yang mendominasi teori dan riset akuntansi keuangan sejak tahun 1968.

Namun kita perlu berhati-hati jika membandingkan kegunaan dengan besarnya perubahan harga saham. Kegunaan ini tidak mengikuti apa yang ingin diperbaiki oleh masyarakat jika pada akuntan mendasarkan keputusannya pada informasi laporan keuangan untuk menyampaikan dasar respon pasar untuk informasi tersebut.

Pertimbangan sosial ini tidak mengesampingkan perspektif informasi. Para akuntan masih bisa berusaha meningkatkan posisi kompetitif mereka dalam pasar informasi dengan menyediakan informasi yang berguna. Dan pasar saham akan lebih efisien dalam perkembangan dimana harga saham merupakan indikator kesempatan investasi yang baik. Namun demikian, apa yang tidak bisa dilakukan oleh akuntan adalah menyatakan bahwa kebijakan akuntansi "terbaik" merupakan kebijakan yang menghasilkan respon pasar terbesar.

\section{Alasan-alasan Respon Pasar}

Perhatikan prediksi berikut mengenai perilaku investor dalam menanggapi informasi laporan keuangan :

1. Para investor memiliki keyakinan awal tentang hasil yang diharapkan dari resiko saham perusahaan.

2. Dengan diumumkannya penghasilan bersih tahun tersebut, investor tertentu akan memutuskan menjadi memiliki lebih banyak informasi dengan menganalisis jumlah penghasilan.

3. Para investor yang telah memperbaharui keyakinan mereka mengenai peningkatan profitabilitas dan hasil di masa mendatang akan cenderung membeli saham perusahaan dengan harga pasar yang berlaku, dan sebaliknya untuk investor yang memperbaharui penurunan keyakinan mereka (evaluasi mereka mengenai resiko saham ini juga bisa direvisi).

4. Kita bisa berharap memeriksa jumlah saham yang diperdagangkan, yang meningkat segera setelah perusahaan melaporkan penghasilan bersihnya.

Dalam suatu penelitian klasik, Beaver (1968) meneliti reaksi volume perdagangan. Dia menemukan peningkatan jumlah besar selama minggu dikeluarkannya pengumuman 
pendapatan.

\section{Mengetahui Respon Pasar}

1. Teori pasar yang efisien menunjukkan bahwa pasar akan bereaksi cepat terhadap informasi baru. Akibatnya, perlu diketahui kapan laporan penghasilan bersih tahun yang bersangkutan diketahui secara umum. Jika peneliti terlambat mencari pengaruh jumlah dan harga, tidak ada pengaruhnya meskipun sudah ada.

2. Berita yang baik (good news) atau buruk (bad news) dalam laporan penghasilan bersih biasanya dievaluasi seperti apa yang diharapkan oleh investor.

3. Ada banyak peristiwa yang terjadi, yang mempengaruhi jumlah dan harga saham perusahaan. Hal ini berarti bahwa respon pasar terhadap penghasilan bersih tang dilaporkan bisa sulit didapatkan. Misalkan suatu perusahaan melepaskan penghasilan bersih tahun tersebut, yang berisi berita baik, pada hari yang sama dengan pemerintah federal mengumumkan peningkatan substansial dalam defisit. Pengumuman tersebut mungkin mempengaruhi harga dari semua atau sebagian besar saham di pasarasan, yang pada gilirannya akan menenggelamkan pengaruh harga dari faktor ini pada hasil saham.

\section{Membandingkan Hasil dan Pendapatan}

Kini peneliti empiris bisa membandingkan hasil saham abnormal pada hari 0 sebagaimana yang dihitung sebelumnya dengan unsur yang tidak diharapkan dari laporan penghasilan bersih perusahaan. Jika penghasilan bersih yang tidak diharapkan ini merupakan "good news" (yakni penghasilan bersih positif yang tidak diharapkan) para investor pada umumnya bereaksi pada berita baik yang tidak diperkirakan dalam hal pendapatan.Jalur dasar pemikiran yang sama berlaku jika pengumuman pendapatan merupakan bad news.

\section{Penelitian Ball dan Brown}

Pada tahun 1968, Ball dan Brown memulai suatu tradisi riset pasar modal empiris dalam akuntansi yang berlanjut sampai saat ini. Mereka adalah yang pertama kali memberikan bukti empiris yang meyakinkan bahwa harga pasar saham perusahaan memberikan respon terhadap muatan informasi laporan keuangan. Ulasan makalahnya bernilai karena metodologi dasar mereka dan adaptasi serta perkembangannya terus digunakan. Makalah mereka terus memberikan pedoman dan juga dukungan bagi orang yang ingin lebih memahami 
kebermanfaatan keputusan dari laporan keuangan.

Tugas pertama Ball dan Brown adalah mengukur muatan informasi pendapatan. Ukuran yang mereka gunakan cukup kasar, yakni apakah pendapatan lebih besar dibandingkan dengan yang diperkirakan oleh pasar (GN) atau lebih kecil daripada yang diperkirakan (BN). Hal ini tentu membutuhkan pengganti untuk perkiraan pasar. Ball dan brown menggunakan dua pengganti. Yang pertama didasarkan pada rancangan akuntansi mereka menyatakan : Pada tahun-tahun yang lalu, jika penghasilan suatu perusahaan berhubungan dengan penghasilan perusahaan yang lain dalam suatu cara tertentu, maka pengetahuan dari hubungan sebelumnya, bersamaan dengan pengetahuan mengenai penghasilan perusahaan lain untuk tahun tersebut, menghasilkan harapan kondisional untuk penghasilan perusahaan saat ini. Maka terpisah dari pengaruh konfirmasi, jumlah informasi baru yang diungkapkan dengan jumlah penghasilan saat ini bisa diperkirakan dengan perbedaan antara perubahan nyata dalam penghasilan dan harapannya (Ball dan Brown, hal 161). Kedua adalah berasumsi bahwa harapan pasar atas pendapatan saat ini sama dengan pendapatan nyata tahun yang lalu, dimana hasil yang tidak diharapkan adalah perubahan pendapatan. Pendekatan time series sederhana memberikan hasil yang sama dengan yang menggunakan rancangan akuntansi.

\section{Alasan Respon Pasar Differensial}

Sejumlah alasan bisa diajukan untuk respon pasar diferensial bagi pendapatan berdasarkan biaya historis. Beta/rancangan. Semakin beresiko urutan hasil masa mendatang yang diharapkan dari suatu perusahaan, semakin rendah nilainya bagi investor yang menentang resiko, hal yang lainnya sama.

Ketetapan merupakan suatu konsep yang menantang dan berguna. Satu alasan yang diajukan oleh Ramakrishnan dan Thomas (1991) adalah bahwa unsur yang berebda dari penghasilan bersih mungkin memiliki ketetapan berebda. Misalnya, bahwa dalam tahun yang sama suatu perusahaan berhasil memperkenalkan produk baru, ia juga melaporkan hasil pada pengurangan pabrik dan peralatan. Maka ketetapan pendapatan adalah rata-rata ketetapan yang berbeda dari komponen pendapatan. Ramakrishnan dan Thomas membedakan tiga jenis peristiwa pendapatan:

- Permanen, diharapkan tetap tanpa batas.

- Sementara, mempengaruhi pendapatan di tahun tersebut namun tidak akan mempengaruhi 
tahun mendatang.

- Ketidaksesuaian harga, ketetapan nol.

\section{Perspektif Pengukuran Tentang Kegunaan Keputusan}

Secara umum tujuan pengungkapan dalam menyajikan informasi yang dipandang perlu untuk mencapai tujuan pelaporan keuangan dan untuk melayani berbagai pihak yang mempunyai kepentingan berbeda-beda dalam kegunaan keputusan pelaporan finansial (Suwardjono, 2005:580). Sejumlah pemikiran menunjukkan bahwa kegunaan keputusan pelaporan finansial di perluas oleh semakin besarnya perhatian terhadap pengukuran. Dari arah empiris, nampak bahwa net income yang dilaporkan hanya menjelaskan bagian kecil variasi security price disekitar tanggal pengumuman pendapatan. Hal ini mengangkat pertanyaan tentang relevansi pelaporan berbasis-biaya historis. Selain itu dari arah empiris, terdapat banyak bukti bahwa security market tidak seefisien yang diyakini sebelumnya. Hal ini menunjukkan bahwa investor membutuhkan lebih banyak bantuan dalam menilai future return (return mendatang) daripada yang mereka dapatkan dari laporan biaya.

Dari arah teoritis, teori clean surplus (surplus bersih) Ohlson menunjukkan bahwa market value perusahaan dapat ditunjukkan menurut laporan income dan variabel neraca lajur. Meskipun teori clean surplus berlaku pada dasar akuntansi, namun buktinya bahwa nilai perusahaan bergantung pada variabel akuntansi mendasar sesuai dengan perspektif pengukuran.

Terakhir, perhatian yang semakin besar terhadap pengukuran didukung dari arah praktek. Dalam beberapa tahun terakhir, auditor menghadapi perkara hukum, khususnya setalah bangkrutnya institusi finansial. Maka, nampak bahwa asset value institusi yang bangkrut terlalu duebihlebihkan. Standar akuntansi yang menuntut marking-to-market, ceiling test, dan teknik berbasiscurrent value lainnya, dalam hal ini membantu menurunkan reliabilitas auditor.

Sekarang kita mengkaji setiap pemikiran ini secara lebih mendetail.

\section{Kekuatan Eksplanatori Net Income}

Pemahaman tentang poin Lev menunjukkan apresiasi perbedaan antara signifikansi statistik dan signifikansi praktek. Statistik seperti ERC dapat sangat berbeda dengan nol namun dapat sangat kecil. Maka, kita sangat yakin bahwa terdapat respon security market terhadap earning (yang bertolak belakang dengan tidak ada respon) namun pada saat yang sama kita 
kecewa bahwa respon tidak Iebih besar dari yang seharusnya. Dengan kata lain, andaikan ratarata security price berubah $\$ 1$ selama short window dari tiga atau empat hari diseputar tanggal pengumuman earning. Maka, poin Lev adalah bahwa hanya sekitar 2-5\% perubahan ini yang disebabkan pengumuman earning saja.

\section{Keganjilan Efficient Security Market}

Tidak ada reaksi market lebih lanjut terhadap berita baik atau buruk tentang carning. Namun, sudah lama diketahui bahwa hal ini tidak benar-benar terjadi. Bagi perusahaan yang melaporkan berita baik tentang earning return tak normalnya cenderung menyimpang keatas setidaknya selama 60 hari seteIah pengumuman earning. Demikian juga perusahaan yang melaporkan berita earning yang buruk mengalami penyimpangan return tak normal kebawah selama periode yang sama. Kita dapat menemukan bukti penyimpangan paska-pengumuman ini pada penelitian Ball dan Brown investor nampaknya mengabaikan implikasi current earning pada future earning. Seperti yang dikatakan Bernard dan Thomas, ditemukan fakta bahwa perubahan earning per kuartal memiliki korelasi positif. Yaitu, jika misalnya sebuah perusahaan meelaporkan GN dalam kuartal ini bahwa earning kuartal ini lebih besar daripada kuartal sama tahun lalu, maka terdapat kemungkinan 50\% bahwa earning kuartal tahun berikutnya akan lebih besar dari pada earning tahun silam. Investor rasional harus mengantisipasi hal ini dan karena mereka menawarkan lebih tinggi harga share perusahaan sebagai respon terhadap GN sekarang, maka mereka juga harus menawar lebih tinggi dikarenakan peningkatan kemungkinan GN pada periode mendatang. Namun, Bernard dan Thomas menunjukkan bukti bahwa hal Ini tidak terjadi, yang menunjukkan bahwa penyimpangan paska-pengumuman disebabkan market yang membutuhkan waktu untuk menghitung hal ini. Laporan informasi memiliki lebih banyak informasi dari pada net income.

\section{Penerapan Kriteria Kegunaan Keputusan}

Penerapan kriteria kegunaan keputusan berdasarkan perspektif informasi dan kegunaan pada pelaporan keuangan (financial reporting) dalam penelitian empiris pasar modal. Dalam pelaporan keuangan akan diungkapkan informasi akuntansi dan nonakuntansi, termasuk biaya historis dan biaya sekarang. Jadi, dengan adanya pengungkapan informasi dengan metode pengukuran dan kandungan informasi akuntansi akan memberikan sinyal positif bagi investor 
sebagaimana dinyatakan peneliti berikut :

1. Merton (1987) menyatakan bahwa informasi asimetri hanya sebagian investor yang mengetahui informasi tentang tiap-tiap perusahan. Jika perusahaan dapat memperbesar himpunan investor yang mengetahui tentang informasi dengan cara melepaskan informasi, maka nilai pasar perusahaan akan mengalami peningkatan.

2. Diamond dan Verrecchia (1991) menggambarkan bahwa pengungkapan informasi sukarela akan bisa mengurangi asimetri informasi antara perusahaan dengan pasar sehingga memfasilitasi perdagangan saham perusahaan.

3. Lang dan Lundholm (1996) yang melakukan pengujian terhadap model Merton menggambarkan bahwa model pengungkapan dengan memberi peringkat oleh analis keuangan terhadap kualitas informasi yang diungkapkan. Jika keadaan tidak berubah, semakin tinggi peringkat yang diberikan analis keuangan kepada kualitas dari pengungkapan informasi, maka semakin besar jumlah analisis yang mengikuti perkembangan perusahaan.

4. Healy, Hutton, dan Palepu (1999) melakukan pengujian tentang implikasi dari model Diamond dan Verrecchia. Mereka juga menggunakan peringkat yang diberikan analis terhadap kualitas dari pengungkapan informasi. Hasil yang didapatkan bahwa perusahaan yang peringkat pengungkapan informasinya lebih tinggi akan mengalami peningkatan signifikan pada kinerja harga saham pada tahun setelah kenaikan peringkat itu.

5. Welker (1995) melakukan penelitian tentang efek dari kualitas pengungkapan informasi terhadap komponen spread antara harga penawaran dalam likuiditas pasar dengan mengendalikan volume perdagangan. Hasilnya adalah ada hubungan negatif signifikan antara kualitas pengungkapan informasi (yang diukur berdasarkan peringkat yang diberikan analis terhadap kualitas pengungkapan informasi) dengan bid-ask spread. Hal ini konsisten dengan prediksi dari model Diamond dan Verrecchia.

6. Botosan (1997) melakukan pengujian secara langsung terhadap kualitas pengungkapan informasi dan biaya kapital dengan sampel 122 perusahaan manufaktur di AS. Hasilnya menunjukkan bahwa kualitas pengungkapan informasi yang lebih tinggi memiliki hubungann signifikan dengan biaya kapital yang lebih rendah, tetapi hanya perusahaan yang tidak banyak diperhatikan oleh analis.

7. Sengupta (1998) melakukan penelitian terhadap dampak dari kualitas pengungkapan informasi terhadap biaya utang. Hasil menunjukkan bahwa rata-rata perusahaan mengalami 
penurunan 0,02 persen pada biaya utang untuk kenaikan 1 persen pada kualitas pengungkapan informasi yang ditentukan berdasarkan peringkat yang diberikan analis keuangan.

\section{PENUTUP}

Dari pembahasan di atas dapat disimpulkan bahwa dengan menggunakan kegunaan keputusan (decision usefulness) maka informasi akuntansi akan lebih reliabel dan relevan. Kegunaan keputusan merupakan suatu pendekatan terhadap laporan keuangan yang berdasarkan biaya historis agar lebih berguna. Selama ini penyajian laporan keuangan harus menekankan pada karateristik kualitatif laporan keuangan, yaitu reliabilitas dan relevansi. Reliabilitas merupakan penyajian informasi yang terkandung di dalam laporan keuangan harus dapat diandalkan jika cukup terbebas dari kesalahan dan penyimpangan merupakan suatu penyajian yang jujur. Sebaliknya, relevansi adalah informasi akuntansi keuangan yang relevan mempunyai pengaruh terhadap keputusan ekonomi yang menggunakan informasi akuntansi keuangan itu. Pendekatan kegunaan keputusan dapat digunakan dengan dua perspektif, yaitu perspektif informasi dan perspektif pengukuran. Perspektif informasi lebih menekankan pada kandungan informasi yang ada dalam laporan keuangan. Sebaliknya, perspektif pengukuran menekankan pada pemilihan metode pengukuran terhadap laporan keuangan.

Hasil diskusi Reserve Recognition Accounting (RRA) menyatakan bahwa tidak mungkin menyiapkan laporan keuangan dengan tingkat reliabilitas dan relevansi secara penuh karena konsekuensinya akan terjadi trade-offs antara reliabilitas dengan revelansi. Oleh karena itu, untuk mengatasi permasalahan tersebut digunakanlah pendekatan kegunaan keputusan (decision usefulness) untuk membuat laporan keuangan yang berdasarkan biaya historis (historical cost) lebih berguna. Salah satu di antaranya adalah dengan adanya pengungkapan penuh (full disclosure).

Pengungkapan penuh informasi yang harus diungkap adalah mengenai data akuntansi dan non akuntansi yang relevan. Hal ini disebut dengan pelaporan keuangan (financial reporting) yang lebih memberikan informasi tambahan selain laporan keuangan, dengan kata lain pelaporan keuangan cakupannya lebih luas daripada laporan keuangan. Menurut Chariri dan Ghozali (2003:235), pengungkapan (disclosure) mengandung arti bahwa laporan keuangan harus memberikan informasi dan penjelasan yang cukup mengenai hasil aktivitas suatu unit usaha. Bukti empiris menyatakan bahwa respons harga sekuritas untuk informasi akuntansi 
menyarankan investor mencari informasi yang berguna (Scott, 2003:466).

\section{DAFTAR PUSTAKA}

Baridwan, Z. 1999. Intermediate Accounting. Edisi Ketujuh. Yogyakarta: BPFE.

Barth, M. E. 2000. "Valuation-Based Research Implications for Financial Reporting and Opportunities for Future Research". Accounting and Finance, 40: 7-31.

Belkoui, A.R. 2001. Teori Akuntansi. Jilid Kedua. Jakarta: Salemba Empat.

Botosan, C.A. 1997. "Disclosure Level and the Cost of Equity Capital". The Accounting Review, hal. 323-349.

Chariri, A. dan Ghozali, I. 2003. Teori Akuntansi. Edisi Revisi. Semarang: Badan Penerbit Universitas Diponegoro.

Deegan, C. (2004) Financial Accounting Theory, McGraw-Hill Australia, NSW, Australia

Diamond, D.W. dan Verrecchia, R.E. 1991. "Disclosure, Liquidity, and the Cost of Capital". The Journal of Finance, hal. 1325-1359

FASB, 1978,Statement of Financial Accounting Conceptes No.1, Objectives of Financial Reporting By Business Enterprises; Stamford, Connecticut

FASB, 1980,Statement of Financial Accounting Concepts No.2,'Qualitative Characteristics of Accounting Informations"; Stamford, Connecticut

Healy, P.M., Hutton, A.P., dan Palepu, K.G. 1999. "Stock Performance and Intermediation Changes Surrounding Sustained Increase in Disclosure". Contemporary Accounting Research, hal. 485-520

Hendriksen, E. S. 1994. Teori Akuntansi. Cetakan Keempat. Jakarta: Erlangga.

Hitz, J. M. 2005. "The Decision Usefulness of Fair Value Accounting-A Theoretical Perspective: Cologne Working Paper on Banking, Corporate Finance, Accounting and Taxation" [On-line] tersedia http://www.wiso.uni-koeln.de.

Ikatan Akuntan Indonesia. 2009. Pernyataan Standar Akuntansi Keuangan, Kerangka Dasar Penyusunan dan Penyajian Laporan Keuangan. Jakarta: Salemba Empat.

Kieso, D. E. dan Weygandt, J. J. 1995. Akuntansi Intermediate. Edisi Ketujuh. Jakarta: Binarupa Aksara.

Lang, M.H. dan Lundholm, R.J. 1996. "Corporate Disclosure Policy and Analyst Behavior”. The Accounting Review, hal 467-492. 
Mardiyah, A. A. 2002. "Pengaruh Informasi Asimetri dan Disclosure terhadap Cost of Capital". Jurnal Riset Akuntansi Indonesia, Vol. 5, No. 2, hal. 229—256.

Merton, R.C. 1987. "A Simple Model of Capital Market Equilibrium with Incomplete Markets". The Journal of Finance, hal. 483-510.

Scott, W.R (2003). Financial Accounting Theory, Prentice-Hall, Toronto, Canada.

Sengupta, P. 1998. "Corporate Disclosure Quality and the Cost of Debt". The Accounting Review, hal. 459-474.

Suwardjono. 2005. Teori Akuntansi Perekayasaan Pelaporan Keuangan. Edisi Ketiga. Yogyakarta: BPFE.

Tandelilin, E. 2001. Analisis Investasi dan Manajemen Portofolio. Edisi Pertama. Yogyakarta: BPFE. 